\title{
Energy, Economic Growth, and Financial Development in ASEAN+3
}

\author{
Kartika Pramahesti ${ }^{1}$, Djoni Hartono ${ }^{2 *}$ \\ ${ }^{*}$ Corresponding author
}

\begin{abstract}
This research aimed to determine the effects of financial development on the consumption of energy through the economic growth channels in ASEAN+3 in 1990 - 2013. Whether or not the financial development affected the energy consumption directly is still unclear, depending on how the efficiency of economic development takes place. The present research tried to complete the slit by evaluating the indirect effects of financial development through economic growth. The GMM method was applied to solve the endogenic problem of the simultaneous equation, resulting in an unbiased and consistent estimator. There was significant positive leverage of both the economic development and urbanization on the utilization of energy, while the cost of energy adversely affected its utilization. Also, there was a significant positive effect of financial growth in banking and share market on the utilization of energy, where the effect of the banking sector was stronger than that of the share market.
\end{abstract}

Keywords: ASEAN+3, economic growth, energy, financial development, simultaneously equation

\begin{abstract}
Abstrak
Penelitian ini bertujuan untuk menentukan dampak dari perkembangan keuangan terhadap konsumsi energi melalui pertumbuhan ekonomi di ASEAN+3 pada tahun 1990 - 2013. Berpengaruh secara langsung atau tidaknya perkembangan keuangan terhadap konsumsi energy masih belum jelas, tergantung pada efisiensi dari pertumbuhan ekonomi itu sendiri. Penelitian ini mencoba menyelesaikan celah dengan mengevaluasi efek tidak langsung dari perkembangan finansial melalui pertumbuhan ekonomi. Metode GMM diaplikasikan untuk menyelesaikan problem endogenitas dari persamaan simultan, sehingga menghasilkan estimator yang tidak bias dan konsisten. Pertumbuhan ekonomi dan urbanisasi secara signifikan berpengaruh positif, sementara itu harga energi secara signifikan berpengaruh negatif terhadap konsumsi energy. Efek secara signifikan dan positif terhadap konsumsi energi juga diperlihatkan dari perkembangan keuangan di sektor perbankan dan pasar saham, yang mana dampak di sektor perbankan lebih kuat dibandingkan di pasar saham.
\end{abstract}

Kata Kunci: ASEAN+3, pertumbuhan ekonomi, energy, perkembangan keuangan, persamaan simultan JEL Classification: O13, O57, Q43

\section{How to Cite:}

Pramahesti, K., \& Hartono, D. (2020). Energy, Economic Growth, and Financial Development in ASEAN+3. Signifikan: Jurnal Ilmu Ekonomi, Vol. 9(1), 137-152. doi: http://dx.doi.org/10.15408/sjie.v9i1.13536. 


\section{Introduction}

International Energy Agency (IEA) projection stated that the world energy demand would increase by $45 \%$ (or an average yearly rate of 1.6\%) until 2030. Fossil fuels supply most of (or about 80\%) the world's energy needs. This trend becomes an issue that will affect world energy demand. Energy demand in Southeast Asia raised by more than 50\% from 2000 to 2013 as a consequence of fast economic and demographic alterations. Therefore, it can lead to an adjustment of the composition and size of energy utilization (IEA, 2015). Since 1971 , the demand for primary energy in Southeast Asia increased by an average of $0.64 \%$ for each presentation on the GDP growth. Recently, the energy consumption sector of ASEAN was relatively low, representing only half of the global average consumption. However, it is expected to increase sharply. Energy needs in Southeast Asia have increased by 2.5 -fold since 1990, and the demand is expected to increase as the population reaches 600 million people with a combined gross domestic product of US\$2.1 trillion (IEA). Asia is still one of the fastest-growing areas, with a GDP percentage rising from 5.9\% to 7.7\%. Statistically, the current population of Asia is about 4.4 Billion, making it the largest population or equaling to $59.78 \%$ of the world's total population; and is projected to keep growing.

Figure 1. Population Distribution Based on Region, 1800-2050

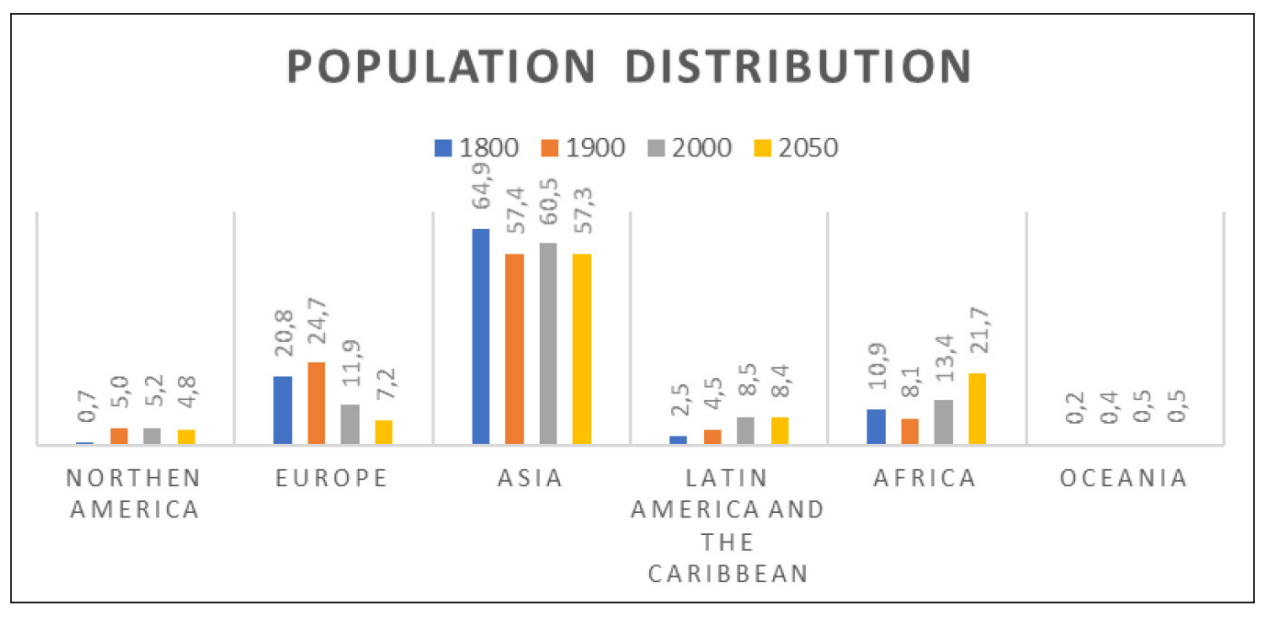

Source: (United Nations, 2007)

Referring to the picture above, Asia has the densest population. In 1800 , about $86 \%$ of the world's inhabitants were in Asia and Europe, in which 65\% of them were in Asia. By 1900 , the population of Europe raised to $25 \%$, driven by the industrial revolution. After the Second World War, the population growth was rapid. The dynamics of population growth would affect the size and pattern of energy consumption as the overall impacts of economic growth include the standard of living, the use of resources and environments presumed to change the landscape of the world (United Nations, 2007).

Previous studies showed the importance of energy in fostering economic productivity. The excrescence of production activities juices up the demand in energy due to the increase in consumption (Shahbaz \& Lean, 2012). In the last-three-decades, research demonstrated sharp relationships between energy consumption and economic growth, and between 
financial development and economic growth. Thus, it makes sense to assume that there are significant linkages between energy consumption and financial development. There are at least three impacts of how financial growth might predispose the energy utilization. Those are the direct impact, business impact, and wealth impact (Sadorsky, 2011). The ambiguity of the theoretical connections between the variables in question can only be solved through empirical analysis (Sadorsky, 2010). Early studies evaluated the impacts of financial variables on energy consumption. Many related studies carried out in developing countries noticed connections between financial development and energy consumption and economic growth. The outcome indicated that the correlations between economic development and utilization of energy could be summarised in three main presumptions: the first assumption affirms the one-way connection of energy utilization to GDP growth; the second assumption represents a positive two-way connections between the utilization of energy and GDP growth (feedback), and the third assumption defines the genuine connection between economic development and energy utilization (neutrality). The first and second presumptions were the most validated by previous research.

Latest references on energy study inserted financial variables in modeling the consumption of energy on the economy. The financial variable is said to affect the energy demand, so it is necessary to put the variable in the study. Besides, most research on the relationship between finance and energy emphasized the direct leverage of energy (Islam et al., 2013; Sadorsky, 2010; Shahbaz \& Lean, 2012; Tang \& Tan, 2014) In reality, financial development indirectly affects energy consumption through economic growth. The growing financial sector will increase the availability of funds allocated to investments, encouraging the growth of industries. The increasing production activity will then boost the economic growth that needs new additional infrastructures. More energy is then needed to run the infrastructures. This is how infrastructure positively affects energy consumption. The efficiency in economic growth surely affects either positively or negatively (Islam et al., 2013; Komal \& Abbas, 2015)

The intensity of energy consumption in each country will differ due to diverse capabilities in adopting technological innovations in the development of the industrial sector (Shahbaz \& Lean, 2012). Thus, the purpose of this paper was to build on Komal and Abbas's (2015) contribution - observing the Association of Southeast Asian Nations (ASEAN)+3. This aspect was not explained in the previous study. The ASEAN+3 regions are the society in Southeast Asia that organize the entire economy, developing trades, and financial integration investments. In this paper, the sample countries were restricted to 8 (Indonesia, Malaysia, Thailand, Philippines, Singapore, China, Japan, and Korea). The selection of ASEAN +3 regions was driven by the development of energy demand and the development of the financial sector in the regions. The Five ASEAN Countries (Indonesia, Malaysia, Thailand, Philippines, and Singapore) are the largest economy in Southeast Asia, receiving \$128.4 billion of foreign investment.

The contribution of this study differs from that of Komal and Abbas (2015) in two aspects. First, two indicators showing the developments of the financial sector were applied. The International Monetary Fund (IMF), through its published data on payments balance, 
showed a connection between the financial growth level and financial accounts. This result was also linked to the international financial flows - both short and long terms for the public and private sectors (Chang, 2014). The financial development based on financial flows, covers financial institutions, including private and public banks, stock markets, and FDI. Financial development indicators are used to assess the growth of financial institutions. The financial development in the banking sector, in terms of size, can be represented by the domestic private credit as a share of the GDP (Gregorio \& Guidotti, 1995) The ratio of the total value of shares traded against GDP can be used to measure developments in the initial level of stock market liquidity. Second, the present study prepared a strong theoretical background to support the empirical analysis. It examined the influence on energy consumption due to financial developments in both banking and stock markets through economic growth.

Consumer behavior theory is used as the basis for the framework in this study to obtain the energy consumption function. This theory assumes that all consumers are rational, reflected by the behavior of maximizing their usefulness following the given budget constraints. Therefore, the energy consumption function is written as follows:

$$
\mathrm{EC}_{\mathrm{t}}=\mathrm{f}\left(\mathrm{Y}_{\mathrm{t}}, \mathrm{PE}_{\mathrm{t}}, \mathrm{Z}_{\mathrm{t}}\right)
$$

Where $\mathrm{EC}_{\mathrm{t}}$ is the consumption of energy, $\mathrm{Y}_{\mathrm{t}}$ is the level of income; $\mathrm{PE}_{\mathrm{t}}$ is the price of energy goods, $Z_{t}$ is a vector of other factors affecting energy consumption. In this paper, urbanization was another factor affecting energy consumption (Ewing \& Rong, 2008; Liddle, 2004; Poumanyvong et al., 2012)

Stern and Cleveland (2004) modified using energy as an input factor in the production function, and the results indicated that energy had a key role in growth. That energy is an important factor is not just two basic input factors because energy is needed in producing other inputs (Omri, 2013; Shahbaz et al., 2013; Sharma, 2010). The extended Cobb-Douglass production function can be written as follows:

$$
Y_{t}=A(t) K(t)^{\alpha} L(t)^{\beta} E(t)^{\gamma}
$$

This equation suggests that the proportion rate of all production factors increments will be equal to the increase of outputs. The latest was introduced around the 1980s, known as endogenous growth theory. Internal growth is referred to as a long-term economic growth at a rate determined by internal factors of the given economic system. The extrinsic characteristics are those controlling the possibilities and inducement to generate technological knowledge. In the long haul, the economic extension rate, estimated by the growth rate of the output per person, will depend on the growth rate of the total productivity factor (TFP). Other aspects include institutions. The Cobb Douglas production function can be written using financial development as an indicator of the role of financial institutions as follows:

$$
Y_{t}=F D(t) K(t)^{\alpha} L(t)^{\beta} E(t)^{\gamma}
$$

FD is financial development; the sectors of financial development used were the banking sector and the stock market. Financial development can increase consumers' access and convenience to obtain productivity factors (Omri et al., 2015). Capital accumulation and technological innovation are parts of the financial sector, driving the growth of the real sector. Moreover, the financial sector serves as a mediator giving less-risk financial products 
and instruments to the borrowers. These increments in the level of investment ultimately accelerated economic growth (Levine, 1997).

The empirical study pointed out that financial depth (bank and stock market development) had a stronger positive impact on growth compared to the financial structure (bank and capital market scale). Financial development influences economic growth (Bekaert et al., 2005; Sadorsky, 2010; Wu et al., 2010) meaning that it may affect energy consumption through economic growth channels. The financial system of a given country will be more efficient due to the significant financial development (Sadorsky, 2010). The sophisticated financial system enables financial institutions to perform more effective and efficient activities. Reformations in financial services such as a cut of information expense, the openness of information, and decent management can lead to investment profitability (Islam et al., 2013; Shahbaz \& Lean, 2012) Arestis et al. (2001) concluded that both credit and stock markets could boost economic growth, but the positive effect of the banking system is stronger. The econometric panel method was applied to investigate the links between economic development, banks, and market shares. It verified whether or not the growth of banks and market shares positively relates to economic development (Beck \& Levine, 2004) They used 40 countries in 1976-1998 through the implementation of the The Generalized Method of Moments (GMM) estimation for panel data analysis. The results confirmed that both the stock market and banks significantly affect economic growth.

The linkage between energy consumption and economic growth attracts the interest of economists and policymakers, as it has a significant policy impact (Saidi \& Hammami, 2015). There are three common views on energy issues and economic growth. The first view states that energy is the input of production, causing causality in the levels of energy consumption affecting economic growth (Stern \& Cleveland, 2004). The second view holds that there is an opposite causal relationship according to which economic growth affects energy consumption (Toman \& Jemelkova, 2003). Next, the third outlook declares a two-way relationship between economic development and energy utilization. A discussion on energy and development began when Kraft and Kraft (1978) researched in the US in 1947-1974. It revealed that the economic growth generated the increased energy demand. Furthermore, many researchers further investigated the two connections through two-way Granger causality, resulting in four testable hypotheses, (a) growth hypothesis, (b) conservation hypothesis, (c) feedback hypothesis, and (d) neutrality hypothesis (Apergis \& Tang, 2013; Jamil \& Ahmad, 2010; Kahsai et al., 2012; Shahbaz et al., 2013) There are different causalities for each country depending on some factors and characteristics, each of which has its uniqueness. Ozturk \& Acaravci (2013) confirmed that low-income countries had a Granger's causality from GDP on energy utilization, while the middle-income countries developed a two-way causality between GDP and energy utilization. Some researchers argued that it is a one-way relationship because of the economic growth of energy consumption. Factors that can cause different causal relationships in some countries include the methods of model estimation used, the troubles caused by non-stationary data, variable options, study period, sample choices, and the countries' growth levels. Cheng (1999), who applied the Granger method in the Indian, from 1952 to 1995 , revealed that causality existed from economic growth to 
energy consumption. Chan \& Lee(1997) used the vector error correction model (VECM) and co-integration techniques to analyze energy consumption behavior in China. They found that energy prices, revenues, and the share of industrial output on state revenues were significant factors having impacts on energy consumption. However, the causality of energy utilization in economic development does not exist. Many studies were conducted to identify the causal connection between economic development and energy utilization, as it has been done in Pakistan by Aqeel \& Butt (2001). They demonstrated that economic development directs energy utilization. Another study confirmed that the utilization of energy negatively affects the real GDP (Squalli, 2007) Also, different results reported that no causality occurred between economic development and energy utilization in low-income countries; meanwhile, the utilization of energy raised due to the economic development in high-income countries (Huang et al., 2008). Furthermore, Bartleet \& Gounder(2010) studied the causalities between energy consumption and multivariate models. They demonstrated that economic growth, employment, and energy consumption had co-integration relationships. The variety of results obtained from previous studies could not ascertain what happened in each region. Thus, further study is needed to determine the causality and co-integration among variables for a given region, especially in the ASEAN +3 region. However, the results showed similarities in which economic growth is directly linked to energy demand or consumption.

In 9 Central and Eastern European countries, showed that financial development could have an impact on energy demand at various levels (Sadorsky, 2011). At the household level, it will be easier and cheaper for consumers to borrow funds to purchase goods or products directly, increasing energy demand. At the industry level, it is easier for entrepreneurs to access capital to grow their business or to create business effects. These effects will build a level of confidence. There is optimism in the economy that leads to increased levels of consumption and energy demand for energy-intensive products. Moreover, Sadorsky(2010) studied 22 developing countries in 1990-2006 using different indicators for financial development. The linkage between energy consumption and the financial development sector has been interesting in recent years as it is still in the early stages. In 2009, Yandan \& Zhang examined the leverage of financial growth on energy demand. The study indicated that Granger's causality existed on energy demand for financial growth in China. Furthermore, in Pakistan, a study verified that financial growth significantly and positively affects energy utilization (Shahbaz et al., 2013). In European countries, financial development has no significant impact on energy consumption. However, it was found that financial development had a powerful impact on energy consumption in the old member states of the European Union. Those results were obtained by (Çoban \& Topcu, 2013). Sadorsky (2011) was inspired by the study conducted by Karanfil (2009), who argued that adding a multivariate model such as domestic credit for the private sector, market share capitalization, or debt can determine the causality between economic growth and energy consumption through energy prices. Similar results were found by Fung (2009), stating that more products would be produced due to an effective financial system. Energy demand will increase as inputs increase for production needs. The background of this study is in line with the most recent researches, one of which is the study conducted by Komal and Abbas (2015). It is based on the same premise that financial development 
can indirectly affect energy consumption in Pakistan. The characteristics of the state and the selection of indicators in financial development are also important. Chang (2014) stated that when domestic and private credits were used as indicators in financial development, the consumption of energy increased in non-high income countries. Meanwhile, energy consumption would slightly decrease in developed countries if the indicators used in the financial development were the total value stock traded and stock-market turnover, especially in high-income countries, with an increase in energy consumption in developing countries with higher-income characteristics.

Early researches revealed that the development of the financial sector plays an important role in energy consumption. A linear equation between energy consumption and financial development was developed, but in reality, financial development affects energy consumption through economic growth, the first indication of which is a change in income per capita. Positive or negative influences depend on the purchasing power of consumers on the income level. This indirect transmission was not clearly articulated in previous researches, especially in the ASEAN +3 regions.

\section{Methods}

The nexus between variables can be investigated through the extended Cobb-Douglas production framework. For the estimation purpose, a multivariate framework is written as the structural model below:

$$
\begin{aligned}
& \ln E C_{i t}=\beta_{10}+\beta_{11} \ln Y_{i t}+\gamma_{12} E P_{i t}+\gamma_{13} U R B_{i t}+\mu_{i t} \\
& \ln Y_{i t}=\beta_{20}+\beta_{21} F D 1_{i t}+\beta_{22} F D 2_{i t}+\beta_{23} \ln \operatorname{In} v_{i t}+\beta_{24} T O_{i t}+\beta_{25} L F_{i t}+v_{i t}
\end{aligned}
$$

Where $\mathrm{EC}_{\mathrm{it}}$ is energy consumption, $\mathrm{Y}_{\mathrm{it}}$ is real GDP, $\mathrm{EP}_{\mathrm{it}}$ represents energy price, $\mathrm{URB}_{\mathrm{it}}$ is urbanization, $\mathrm{FD}_{\mathrm{it}}$ is financial development (consisting of banking and stock market indicators in this paper), $\operatorname{Inv}_{\mathrm{it}}$ denotes investment, $\mathrm{TO}_{\mathrm{it}}$ is trade openness, $\mathrm{LF}_{\mathrm{it}}$ is labor force, $\mu_{\mathrm{it}}$ and $v_{\mathrm{it}}$ are stochastic error terms. Panel data were used in this paper. Therefore, i denotes country $(\mathrm{i}=1, \ldots ., 8)$, and $\mathrm{t}$ denotes time in years $(\mathrm{t}=1990, \ldots ., 2013)$, and some of the variables such as $\mathrm{EC}, \mathrm{Y}$, and Inv are subjects to logarithm natural.

In the present study, the economic growth and energy consumption were endogenous variables, while the financial development was considered as an exogenous variable. Verbeek (2012) stated that if the independent variable in the model is endogenous, the estimation with OLS becomes biased and inconsistent. Thus, a better estimation technique is required, one of which is the instrumental estimation of variables. The instrumental variable model can be represented in terms of equations. Therefore, inconsistent estimations and possible biases are obtained when using Ordinary Least Square (OLS) regression. In the case of the endogenic problem, the GMM approach is employed as a set of instrumental variables to figure out these matters allowed by steady and streamlined estimates in the existence of arbitrary heteroscedasticity.

The data used in this research were panel data, i.e., a combination of cross-section data and time series. Some advantages of using panel data are more informative, varied, small probability of collinearity between variables, degree of freedom, and efficiency (Baltagi et al., 
2009). The study used annual data for 5 ASEAN + 3 countries for 13 years (1990-2013). The selection of the period was based on the availability of data and the period of financial crises in 1998 and 2008. The five ASEAN countries were selected together with other 3 countries based on economic growth, the level of energy consumption, and financial development (more than that is the experience of the countries facing crisis).

Table 1. Names, Definitions, and Sources of Variables

\begin{tabular}{|c|c|c|}
\hline Variables & Definition & Sources \\
\hline Energy Consumption & $\begin{array}{l}\text { Represents the usage of main energy before its transformation } \\
\text { into other end-use fuels, equal to the initial outputs plus imports } \\
\text { and stock changes, minus exports and fuels supplied to ships } \\
\text { and aircraft engaged in global transport. }\end{array}$ & (WDI, 2016) \\
\hline Energy Price & $\begin{array}{l}\text { Proxy real energy price variable (roil) is constructed by deflating } \\
\text { the price of West Texas Intermediate (WTI) (measured in US } \\
\text { dollars) to the country's consumer price index in every country. }\end{array}$ & IEA \\
\hline Urbanization & $\begin{array}{l}\text { It is referred to as the people living in urban areas as defined by } \\
\text { national statistical offices. It is determined using the World Bank } \\
\text { population data and urban ratios from the United Nations World } \\
\text { Urbanization Prospects. }\end{array}$ & (WDI, 2016) \\
\hline $\begin{array}{l}\text { Gross Domestic } \\
\text { Product }\end{array}$ & $\begin{array}{l}\text { It is defined as the sum of gross value added from all producing } \\
\text { residents in the economy, plus any product taxes and minus any } \\
\text { subsidies (not included in the value of the products). The data } \\
\text { are in a constant } 2010 \text { U.S. dollars. }\end{array}$ & (WDI, 2016) \\
\hline $\begin{array}{l}\text { Financial } \\
\text { Development }\end{array}$ & $\begin{array}{l}\text { It describes the financial capital granted to the private sector } \\
\text { through loans, trade credits, purchases of non-equity securities, } \\
\text { and other receivable accounts that can set up a claim for } \\
\text { reimbursement. }\end{array}$ & (WDI, 2016) \\
\hline $\begin{array}{l}\text { Financial } \\
\text { Development }\end{array}$ & Total shares traded on the stock market exchange to GDP. & (WDI, 2016) \\
\hline Investment & $\begin{array}{l}\text { It calls for land developments, machinery, plant, and equipment } \\
\text { procurement, and construction of roads, railways, and others. } \\
\text { It also requires hospitals, schools, offices, private residential } \\
\text { dwelling, and commercial and industrial buildings. }\end{array}$ & (WDI, 2016) \\
\hline Trade Openness & $\begin{array}{l}\text { Trade is the sum of exports and imports of goods and services } \\
\text { measured as a share of gross domestic product. }\end{array}$ & (WDI, 2016) \\
\hline Labor Force & $\begin{array}{l}\text { It consists of people aged } 15 \text { and older, meeting the International } \\
\text { Labor Organization's definition of an economically active } \\
\text { population. The latter refers to all people supplying labors } \\
\text { for the production of goods and services in a given period. It } \\
\text { encompasses both the employed and the unemployed. }\end{array}$ & (WDI, 2016) \\
\hline
\end{tabular}

The World Development Indicators (WDI) database provided data on energy utilization in ASEAN +3 countries in 1990-2013. Intermediary development and stock market development are two aspects of financial development at the domestic level. This study decided to use both indicators (banking and stock market) that were available from 1990 to 2013 to enrich contributions from previous studies. The domestic credit to the private sector towards GDP was widely used as a financial development indicator (Komal 
\& Abbas, 2015; King \& Levine, 1993). Meanwhile, not all countries have available data on energy prices. The CPI is not a fit proxy for energy prices, according to Sadorsky (2010); therefore, a proxy of real energy price variable (roil) is constructed by deflating the price of West Texas Intermediate (WTI) (measured in US dollars) to each country's consumer price index. Table 1 presents the variables used for estimation described by definitions, measures and data sources.

\section{Result and Discussion}

The estimation results of Equation (4) are reported in Appendix A. The estimation showed that economic growth reflected by real GDP, energy price, and urbanization are significantly linked with energy consumption. However, the effect was different for every variable. As a panel result, economic growth and urbanization positively affected the utilization of energy. Meantime, the energy price negatively affected energy consumption, which was in line with a demand theory stating that the demand increases when the price of a good decreases. Economic growth has a significant positive effect on energy consumption in all countries, except Indonesia and Singapore. This result is following past studies (Jamil \& Ahmad, 2010; Kahsai et al., 2012; Komal \& Abbas, 2015; Masih \& Masih, 1997; Sadorsky, 2011; Tang \& Tan, 2014). Energy prices in Philipines, Japan and Korea have significantly brought negative impact on energy consumption. As the energy prices rise, the level of energy consumption in those three countries has significantly decreased. This case mostly occured in countries where the energy policy is well implemented, for example, in countries with highly utilized of public transportation. On the contrary, the opposite effect has been found in China in which based on the data in 1990 - 2013, showed that higher energy prices were followed by higher energy consumption. It happened due to energy prices that are relatively cheaper compared to other countries, and the energy subsidy scenario is still high for the final consumers.

Thus, as indicated in this paper, any change in energy prices can be concluded to have a negligible effect on energy utilization. In relation with urbanization, there were only 3 out of 8 countries gaining significant positive effect on energy utilization. This result corroborated the finding from Poumanyvong et al.(2012) that showed negative linkage between urbanization and energy utilization through the coefficient of Singapore, Japan and China. Meanwhile, in panel estimation, urbanization exhibited a significant positive impact on overall energy consumption in ASEAN countries + 3 regions. This result was also consistent with the study conducted by Sadorsky (2011) and Komal and Abbas (2015).

The estimation results of Equation (5) are reported in Appendix B. The results indicated that financial development in the banking sector had a statistically significant positive effect to economic growth, only in 4 countries. The opposite relationship applies to the Philippines; the banking sector has a significant negative effect on per capita income of $0.32 \%$. There is no significant relationship among other countries. Meanwhile, in terms of the stock market sector, there was a statistically significant impact on income per capita in all ASEAN +3 regions excepts China. This result suggests that a well-developed financial system can attract investors both in the banking sector and capital markets and will eventually improve the 
economic growth represented by income per capita. These results were also consistent with previous studies (Beck \& Levine, 2004; Shahbaz \& Lean, 2012). However, the effect in the banking system showed stronger results on the GDP (higher value); this was consistent with the study by Arestis et al. (2001)

Meanwhile, in terms of investment variables, significant influence occurred only in some countries such as Indonesia, Malaysia, China, and Japan. The influence linkage was positive, except in Japan. Besides, trade variables were only significant in Indonesia, Thailand, Japan, and Korea. Nevertheless, investment and trade variables significantly and positively affected the economic growth panel.

Table 2. Effects of Banking-Financial Development on Energy Consumption

\begin{tabular}{cccc}
\hline Channel Variable & FD1 Effect on GDP & GDP Effect on EC & FD1 Effect on EC \\
\hline GDP & $0.187^{* * *}$ & $0.264^{* * *}$ & $0.451^{* * *}$ \\
Wald test (p-value) & & & $42.1667(0.0000)$ \\
\hline
\end{tabular}

Source: Author's calculation, 2019

Following Komal and Abbas (2015), through economic growth that is translated into equality systems, the present study revealed the impacts of financial development on the consumption of energy. The two corresponding coefficients were simultaneously aligned with zero based on the null hypothesis. The rejection of the null hypothesis showed the significance of the combined coefficients resolved by the test (see Table 2). The joint significance of the two terms predicted in the equations (4) and (5) was tested using the Wald test. The test statistic was calculated based on unlimited regression by imposing the approximate coefficient limitation and following the chi-square distribution (based on the null hypothesis without relationship) (Arellano \& Bond, 1991).

Table 3. Effects of Stock Market-Financial Development on Energy Consumption

\begin{tabular}{cccc}
\hline Channel Variable & Effect FD2 on GDP & Effect GDP on EC & Effect FD2 on EC \\
\hline GDP & $0.171^{* * *}$ & $0.264^{* * *}$ & $0.435^{* * *}$ \\
Wald test (p-value) & & & $34.4013(0.0000)$ \\
\hline
\end{tabular}

Source: Author's calculation, 2019

These results showed the elasticity of the effects of the financial sector development on economic growth; and the economic growth on the consumption of energy. A coefficient of 0.451 for the banking sector indicated that a $1 \%$ increase in banking-financial development results in a $0.45 \%$ increase in energy consumption through per capita income effects. Meanwhile, a coefficient value of 0.435 in the stock market sector indicates that a $1 \%$ increase in stock market-financial development produces a $0.44 \%$ increase in energy consumption through per capita income effects. The present study demonstrated that the banking sector has a greater influence on energy consumption than the financial development of the stock market. This 
positive relationship between financial development and energy consumption was consistent in previous researches (Çoban \& Topcu, 2013; Islam et al., 2013; Sadorsky, 2010, 2011; Shahbaz \& Lean, 2012). This study supports, as in the study by Komal and Abbas (2015), that financial development has a significant positive relationship with energy consumption through the effects on economic growth (indirect effects). It can be proposed that the measurements of the impacts of financial development on energy consumption (whether using stock market or banking variables); and on the financial development; make access to technological progress easier to control energy consumption, leading to energy efficiency.

\section{Conclusion}

This study aimed to empirically evaluate the impacts of financial development on the consumption of energy through economic growth in ASEAN + 3. The system of equations was simultaneously estimated to examine indirect linkages. Associated with the potencies in influencing energy consumption, energy prices and urbanization were incorporated into the model. The GMM was used to estimate the structural model of energy consumption and the economic growth channels. The present study used annual time series data covering the period of 1990-2013. The proxy used for financial development is still general, i.e., the amount of credit and the total value of shares sold. Future research may use a more focused proxy aimed at financing or invest in the energy sector. This research used static panel data with a limited-time size; further research can employ dynamic panel data to analyze a longer period and similarity of impacts occurring in each country.

Our empirical result verified the existence of the demand theory in energy commodity. In addition, this study also summarized policy implication that may important to be considered in the process of financial development. For instance, in terms of energy policy regulation, the banking sector plays important role particularly when it comes to the subsidy system in order to avoid energy policy failure such as shown by insignificant effect of energy prices on energy consumption in Indonesia, Thailand and Singapore.

\section{References}

Apergis, N., \& Tang, C. F. (2013). Is the Energy-Led Growth Hypothesis Valid? New Evidence from a Sample of 85 Countries. Energy Economics, 38, 24-31. https://doi. org/10.1016/j.eneco.2013.02.007.

Aqeel, A., \& Butt, M. S. (2001). The Relationship Between Energy Consumption and Economic Growth in Pakistan. Asia-Pacific Development Journal, 8(2), 101-110. https://doi.org/10.1016/j.enpol.2009.08.008

Arellano, M., \& Bond, S. (1991). Some Tests of Specification for Panel Data: Monte Carlo Evidence and an Application to Employment Equations. The Review of Economic Studies, 58(2), 277-297.

Arestis, P., Demetriades, P., \& Luintel, K. (2001). Financial Development and Economic Growth: The Role of Stock Markets. Journal of Money, Credit and Banking, 33(1), $16-41$. 
Baltagi, B. H., Demetriades, P. O., \& Hook, S. (2009). Financial Development and Openness : Evidence from Panel Data. Journal of Development Economics, 89(2), 285-296. https:// doi.org/10.1016/j.jdeveco.2008.06.006

Bartleet, M., \& Gounder, R. (2010). Energy Consumption and Economic Growth in New Zealand: Results of Trivariate and Multivariate Models. Energy Policy, 38(7), 35083517. https://doi.org/10.1016/j.enpol.2010.02.025.

Beck, T., \& Levine, R. (2004). Stock Markets, Banks, and Growth: Panel Evidence. Journal of Banking and Finance, 28(3), 423-442. https://doi.org/10.1016/S03784266(02)00408-9

Bekaert, G., Harvey, C. R., \& Lundblad, C. (2005). Does Financial Liberalization Spur Growth? Journal of Financial Economics, 77(1), 3-55. https://doi.org/10.1016/ j.jfineco.2004.05.007

Chan, H. L., \& Lee, S. K. (1997). Modelling and Forecasting the Demand for Coal in China. Energy Economics, 19(3), 271-287. https://doi.org/10.1016/S0140-9883(96)01019-5.

Chang, S. C. (2014). Effects of Financial Developments and Income on Energy Consumption. International Review of Economics and Finance, 35, 28-44. https://doi.org/10.1016/j. iref.2014.08.011

Cheng, B. S. (1999). Causality Between Energy Consumption and Economic Growth in India: An Application of Cointegration and Error-Correction Modeling. Indian Economic Review, 34(1), 39-49.

Çoban, S., \& Topcu, M. (2013). The Nexus Between Financial Development and Energy Consumption in the EU: A Dynamic Panel Data Analysis. Energy Economics, 39, 8188. https://doi.org/10.1016/j.eneco.2013.04.001

Ewing, R., \& Rong, F. (2008). The Impact of Urban Form on U.S. Residential Energy Use. Housing Policy Debate, 19(1), 1-30. https://doi.org/10.1080/10511482.2008.9521624

Fung, M. K. (2009). Financial Development and Economic Growth: Convergence or Divergence? Journal of International Money and Finance, 28(1), 56-67. https://doi. org/10.1016/j.jimonfin.2008.08.001

Gregorio, J. De, \& Guidotti, P. (1995). Financial Development and Economic Growth. World Development, 23(3), 443-448. https://doi.org/10.1016/0305-750X(94)00132-I.

Huang, B.-N., Hwang, M. J., \& Yang, C. W. (2008). Causal Relationship Between Energy Consumption and GDP Growth Revisited: A Dynamic Panel Data Approach. Ecological Economics, 67(1), 41-54. https://doi.org/10.1016/j.ecolecon.2007.11.006.

Islam, F., Shahbaz, M., Ahmed, A. U., \& Alam, M. M. (2013). Financial Development and Energy Consumption Nexus in Malaysia: A Multivariate Time Series Analysis. Economic Modelling, 30, 435-441. https://doi.org/10.1016/j.econmod.2012.09.033.

Jamil, F., \& Ahmad, E. (2010). The Relationship Between Electricity Consumption, Electricity Prices and GDP in Pakistan. Energy Policy, 38(10), 6016-6025. https://doi. org/10.1016/j.enpol.2010.05.057.

Kahsai, M. S., Nondo, C., Schaeffer, P. V., \& Gebremedhin, T. G. (2012). Income Level and 
The Energy Consumption-GDP Nexus: Evidence from Sub-Saharan Africa. Energy Economics, 34(3), 739-746. https://doi.org/10.1016/j.eneco.2011.06.006.

Karanfil, F. (2009). How Many Times Again Will We Examine the Energy-Income Nexus Using a Limited Range of Traditional Econometric Tools? Energy Policy, 37(4), 11911194. https://doi.org/10.1016/j.enpol.2008.11.029.

King, R. G., \& Levine, R. (1993). Finance Entrepreneurships and Growth: Theory and Evidence. Journal of Moneterary Economics, 32(3), 513-542. https://doi.org/10.1016/ 0304-3932(93)90028-E.

Komal, R., \& Abbas, F. (2015). Linking Financial Development, Economic Growth and Energy Consumption in Pakistan. Renewable and Sustainable Energy Reviews, 44, $211-$ 220. https://doi.org/10.1016/j.rser.2014.12.015

Kraft, J., \& Kraft, A. (1978). On The Relationship Between Energy and GNP. Journal of Energy Development, 3(2), 401-403.

Levine, R. (1997). Financial Development and Economic Growth: Views and Agenda. Journal of Economic Literature, 35(2), 688-726.

Liddle, B. (2004). Demographic Dynamics and Per Capita Environmental Impact: Using Panel Regressions and Household Decompositions to Examine Population and Transport. Population and Environment, 26(1), 23-39. https://doi.org/10.1023/B:POEN .0000039951.37276.f3

Masih, A. M. M., \& Masih, R. (1997). On the Temporal Causal Relationship Between Energy Consumption, Real Income, and Prices: Some New Evidence from Asian-Energy Dependent NICs Based on a Multivariate Cointegration/Vector Error-Correction Approach. Journal of Policy Modeling, 19(4), 417-440. https://doi.org /10.1016/ S0161-8938(96)00063-4.

Omri, A. (2013). CO2 Emissions, Energy Consumption and Economic Growth Nexus in MENA Countries: Evidence from Simultaneous Equations Models. Energy Economics, 40, 657-664. https://doi.org/10.1016/j.eneco.2013.09.003

Ozturk, I., \& Acaravci, A. (2013). The Long-run and Causal Analysis of Energy, Growth, Openness and Financial Development on Carbon Emissions in Turkey. Energy Economics, 36, 262-267. https://doi.org/10.1016/j.eneco.2012.08.025.

Poumanyvong, P., Kaneko, S., \& Dhakal, S. (2012). Impacts of Urbanization on National Residential Energy Use and CO2 Emissions: Evidence from Low-, Middle- and HighIncome Countries. IDEC DP Series. 2(5), 1-35. Graduate School for International Development and Cooperation (IDEC) Hiroshima University.

Sadorsky, P. (2010). The Impact of Financial Development on Energy Consumption in Emerging Economies. Energy Policy, 38(5), 2528-2535. https://doi.org/10.1016/ j.enpol.2009.12.048.

Sadorsky, P. (2011). Financial Development and Energy Consumption in Central and Eastern European Frontier Economies. Energy Policy, 39(2), 999-1006. https://doi. org/10.1016/j.enpol.2010.11.034. 
Saidi, K., \& Hammami, S. (2015). The Impact of CO2 Emissions and Economic Growth on Energy Consumption in 58 Countries. Energy Reports, 1, 62-70. https://doi. org/10.1016/j.egyr.2015.01.003

Shahbaz, M., Hye, Q. M. A., Tiwari, A. K., \& Leitão, N. C. (2013). Economic Growth, Energy Consumption, Financial Development, International Trade and CO2 Emissions in Indonesia. Renewable and Sustainable Energy Reviews, 25, 109-121. https://doi. org/10.1016/j.rser.2013.04.009

Shahbaz, M., \& Lean, H. H. (2012). Does Financial Development Increase Energy Consumption? The Role of Industrialization and Urbanization in Tunisia. Energy Policy, 40, 473-479. https://doi.org/10.1016/j.enpol.2011.10.050.

Sharma, S. S. (2010). The Relationship Between Energy and Economic Growth: Empirical Evidence from 66 Countries. Applied Energy, 87(11), 3565-3574. https://doi.org/ 10.1016/j.apenergy.2010.06.015

Squalli, J. (2007). Electricity Consumption and Economic Growth: Bounds and Causality Analyses of OPEC Members. Energy Economics, 29(6), 1192-1205. https://doi.org/ 10.1016/j.eneco.2006.10.001.

Stern, D. I., \& Cleveland, C. J. (2004). Energy and Economic Growth. In Rensselaer Working Papers in Economics (Vol. 0410). https://doi.org/10.1016/0019-8501(71)90004-6

Tang, C. F., \& Tan, B. (2014). The Linkages Among Energy Consumption, Economic Growth, Relative Price, Foreign Direct Investment, and Financial Development in Malaysia. Quality \& Quantity: International Journal of Methodology, 48(2), 781-797.

Toman, M. T., \& Jemelkova, B. (2003). Energy and Economic Development: An Assessment of The State of Knowledge. The Energy Journal, International Association for Energy Economics, 0, 93-112.

United Nations. (2007). World Population Prospects: The 2006 Revision, Highlights, Working Paper No. ESA/P/WP.202.

Verbeek, M. (2012). A Guide to Modern Econometrics, $4^{\text {th }}$ edition. New York: John Wiley \& Sons.

World Bank. (2016). World Bank Development Indicators, The World Bank Group. Washington DC: World Bank.

Wu, J. L., Hou, H., \& Cheng, S. Y. (2010). The Dynamic Impacts of Financial Institutions on Economic Growth: Evidence from the European Union. Journal of Macroeconomics, 32(3), 879-891. https://doi.org/10.1016/j.jmacro.2009.09.003

Yandan, \& Zhang, L. (2009). Financial Development and Energy Consumption: An Empirical Research Based on Guangdong Province. 2009 International Conference on Information Management, Innovation Management and Industrial Engineering, ICIII 2009, 3, 102-105. https://doi.org/10.1109/ICIII.2009.334 
Kartika Pramahesti Energy, Economic Growth, and Financial Development

\section{Appendix A}

GMM estimates for model Eq. (3.3)

\begin{tabular}{|c|c|c|c|c|}
\hline \multirow[t]{2}{*}{ Independent variable } & \multicolumn{4}{|c|}{ Dependent Variable: Energy Consumption } \\
\hline & Intercept & Economic Growth & Energy Price & Urbanization \\
\hline Indonesia & 3,357 & 0,045 & $-0,023$ & 0,768 \\
\hline (P-value) & $0,000^{* * *}$ & 0,652 & 0.4472 & $0,000^{* * *}$ \\
\hline Malaysia & $-1,123$ & 0,463 & $-0,002$ & 1,132 \\
\hline (P-value) & 0,243 & $0,087^{*}$ & 0,956 & $0,012^{* *}$ \\
\hline Phillipines & $-28,124$ & 1,192 & $-0,118$ & 6,568 \\
\hline (P-value) & $0,013^{* *}$ & $0,004^{* *}$ & $0,000^{* * *}$ & $0,004^{* * *}$ \\
\hline Singapore & 15,803 & $-0,670$ & 0,224 & $-0,680$ \\
\hline (P-value) & 0,150 & 0,496 & 0,574 & 0,485 \\
\hline Thailand & $-3,025$ & 1,049 & $-0,081$ & 0,404 \\
\hline (P-value) & $0.002^{* * *}$ & $0.005^{* * *}$ & 0.1587 & 0.4965 \\
\hline China & 12,488 & 2,853 & 0,286 & $-7,412$ \\
\hline (P-value) & $0.0000^{* * *}$ & $0,001^{* * *}$ & $0.0001^{* * *}$ & $0.0031^{* * *}$ \\
\hline Japan & $-12,021$ & 2,287 & $-0,079$ & $-0,922$ \\
\hline (P-value) & $0.0083^{* * *}$ & $0.0001^{* * *}$ & $0.0579^{*}$ & 0.1416 \\
\hline Korea Rep & $-2,250$ & 0,928 & $-0,119$ & 0,332 \\
\hline (P-value) & 0.7880 & $0.0067^{* * *}$ & $0.0329^{* *}$ & 0.8985 \\
\hline Panel & 3,933 & 0,264 & $-0,0476$ & 0,0236 \\
\hline (P-value) & $0,0000^{* * *}$ & $0,0009^{* * *}$ & $0,0394^{* *}$ & $0,0000^{* * *}$ \\
\hline $\mathrm{R} 2$ & 0,984 & & & \\
\hline Adjusted R2 & 0,984 & & & \\
\hline Durbin-Watson & 0,363 & & & \\
\hline J-Statistic ( $p$-value) & 3,850 & $(0,0497)$ & & \\
\hline
\end{tabular}

Note: ${ }^{* * *},{ }^{* * *}$ Significance at $1 \%, 5 \%$ and $10 \%$ respectively

Source: Authors processed 


\section{Appendix B}

GMM estimates for model Eq. (3.4)

\begin{tabular}{|c|c|c|c|c|c|c|}
\hline \multirow{2}{*}{$\begin{array}{l}\text { Independent } \\
\text { variable }\end{array}$} & \multicolumn{6}{|c|}{ Dependent Variable : Economic Growth } \\
\hline & Intercept & FD 1 & FD 2 & Investment & Trade & Labor Force \\
\hline Indonesia & 9,291 & 0,002 & 0,125 & 0,018 & $-0,216$ & 1,743 \\
\hline (P-value) & $0,000^{* * *}$ & 0,986 & $0,041^{* *}$ & $0,089^{*}$ & $0,041^{* *}$ & $0,058^{*}$ \\
\hline Malaysia & 13,866 & 0,051 & 0,055 & 0,009 & 0,194 & 7,027 \\
\hline (P-value) & $0,000^{* * *}$ & 0,600 & $0,084^{*}$ & $0,000^{* * *}$ & 0,374 & $0,000^{* * *}$ \\
\hline Phillipines & 11,812 & $-0,322$ & 0,096 & $-0,013$ & 0,175 & 4,416 \\
\hline (P-value) & $0,000^{* * *}$ & $0,072^{*}$ & $0,070^{*}$ & 0,422 & 0,417 & $0,000^{* * *}$ \\
\hline Singapore & 6,134 & 0,568 & 0,166 & $-0,006$ & 0,469 & 2,483 \\
\hline (P-value) & $0,046^{* *}$ & $0,002^{* * *}$ & $0,009^{* * *}$ & 0,604 & 0,297 & $0.000^{* * *}$ \\
\hline Thailand & 3,701 & 0,401 & 0,096 & 0,004 & 0,711 & 1,973 \\
\hline (P-value) & $0,0052^{* * *}$ & $0,000^{* * *}$ & $0.000^{* * *}$ & 0.2862 & $0,0003^{* * *}$ & $0,007^{* * *}$ \\
\hline China & 27,724 & $-0,720$ & 0,049 & 0,050 & $-0,358$ & 31,721 \\
\hline (P-value) & $0,042^{* *}$ & 0.2184 & 0,658 & $0.0000^{* * *}$ & 0.4417 & $0,049^{* *}$ \\
\hline Japan & 10,816 & $-0,040$ & $-0,026$ & $-0,005$ & 0,217 & 0,704 \\
\hline (P-value) & $0.0000^{* * *}$ & 0.4031 & $0,0007^{* * *}$ & $0.0000^{* * *}$ & $0,000^{* * *}$ & $0,0034^{* * *}$ \\
\hline Korea Rep & 11,697 & 0,133 & 0,064 & 0,002 & 0,102 & 4,737 \\
\hline (P-value) & $0.0000^{* * *}$ & $0,000^{* * *}$ & $0,0001^{* * *}$ & 0.1830 & $0.0037^{* * *}$ & $0,000^{* * *}$ \\
\hline Panel & 8,900 & 0,187 & 0,171 & 0,006 & 0,203 & 3,568 \\
\hline (P-value) & $0,000^{* * *}$ & $0,000^{* * *}$ & $0,000^{* * *}$ & $0,018^{* *}$ & $0,004^{* * *}$ & $0,000^{* * *}$ \\
\hline $\mathrm{R} 2$ & 0,686 & & & & & \\
\hline Ajusted R2 & 0,677 & & & & & \\
\hline Durbin-Watson & 0,226 & & & & & \\
\hline J-Statistic (p-value) & 3,130 & & & & & \\
\hline
\end{tabular}

Note: ${ }^{* * *},{ }^{* *}$ Significance at $1 \%, 5 \%$ and $10 \%$ respectively

Source: Authors processed 